\title{
Pengembangan Model Latihan Teknik Dasar Pukulan Lob dan Smash Bulutangkis Usia 8-12 Tahun di PB IMARA Kota Kediri Berbasis Android
}

\author{
Brigita Cecilia Armanda*, Sapto Adi, Prisca Widiawati \\ Universitas Negeri Malang, Jl. Semarang No. 5 Malang, Jawa Timur, Indonesia \\ *Penulis korespondensi, Surel: brigitaceciliaarmanda@gmail.com
}

Paper received: 1-10-2021; revised: 19-10-2021; accepted: 25-10-2021

\begin{abstract}
The research aim to develop a basic technique model of lob punches that combined a badminton smash in the from of video that uses android application media. The method of this research is using Research and Development. The subject of this research is badminton athlete PB IMARA. The athlete has age criteria between 8-12 years with the number 30 athlete. The based on needs analysis that a badminton athlete PB IMARA Kediri are still deficiency on the skill level of accuracy of lob punches with smash badminton, this is known when athletes perform training activities. lack of variation lob punches with a badminton smash. data analysis result of data analysis of the validation badminton expert the percentage of 86 percent very valid category, media expert the percentage of 90 percent very valid category, then of a small groups trials with subject 8 athlete the percentage of 88 percent very valid category, the result of a large group trials with subject 22 athlete the percentage of 91 percent very valid category. Concluded a based of table classification appropriateness that a product development classified very valid and feasible use.
\end{abstract}

Keywords: training model; lob and smash badminton; android application

\begin{abstract}
Abstrak
Penelitian ini bertujuan untuk mengembangkan produk berupa model latihan teknik dasar pukulan lob yang dikombinasikan dengan pukulan smash bulutangkis berupa video menggunakan media aplikasi berbasis android. metode dari penelitian ini menggunakan Research and Development. Subjek yang diteliti adalah atlet bulutangkis PB IMARA Kota Kediri yang mempunyai kriteria usia 812 tahun dengan jumlah 30 atlet. Berdasarkan hasil analisis kebutuhan bahwa atlet di PB IMARA Kota Kediri masih kurang pada tingkat keterampilan akurasi pukulan lob dengan pukulan smash, hal tersebut diketahui ketika atlet melakukan kegiatan latihan. Kurang adanya variasi pukulan lob dengan pukulan smash bulutangkis. Hasil analisis data dengan validasi oleh ahli bulutangkis persentase sebesar 86 persen kategori sangat valid, ahli media persentase sebesar 90 persen kategori sangat valid, selanjutnya dari uji coba kelompok kecil oleh 8 atlet persentase sebesar 88 persen kategori sangat valid, uji coba kelompok besar oleh 22 atlet persentase sebesar 91 persen kategori sangat valid. Disimpulkan berdasarkan tabel klasifikasi kelayakan dari produk pengembangan yang dihasilkan, hingga memenuhi kriteria sangat valid dan layak digunakan.
\end{abstract}

Kata kunci: model latihan; lob dan smash bulutangkis; aplikasi android

\section{Pendahuluan}

Berkembangnya olahraga di Indonesia dapat dilihat dari berbagai kejuaraan olahraga dari kejuaraan tingkat lokal hingga tingkat internasional. Aktivitas olahraga merupakan alat yang dapat dijadikan sebagai perangsang pertumbuhan dan perkembangan jasmani, rohani, dan sosial (Yuliatin, E., \& Noor, 2012:10). Kegiatan olahraga dapat dijadikan sebagai tontonan, mata pencaharian serta upaya dalam meningkatkan prestasi. Aktivitas olahraga dikatakan sebagai kegiatan berlatih yang bertujuan meningkatkan kemampuan dan keterampilan gerak dasar sesuai cabang olahraga masing-masing (Aditia, 2015) 
Olahraga bulutangkis yaitu salah satu cabang olahraga yang masuk dalam kategori permainan, bersifat individu dengan kelompok permainan tunggal dan ganda dimainkan oleh anak-anak hingga dewasa yang memiliki keterampilan dasar hingga keterampilan yang paling kompleks (Mangun et al., 2017). Untuk dapat meraih kemenangan dalam pertandingan, seorang atlet harus memiliki kemampuan bertanding dengan baik dalam mendukung pencapaian prestasi dengan program pembinaan yaitu program dalam bentuk training camp bagi para atlet (Bafirman, 2013). Seorang atlet bulutangkis harus menguasai berbagai keterampilan dalam bulutangkis, keterampilan yang harus dikuasai diantaranya adalah pegangan raket (grip), olah kaki (footwork), teknik pukulan seperti service, lob, smash, dropshot, dan drive (Michael Phomsoupha \& Laffaye, 2015).

Seiring perkembangan zaman, penggunaan media pembelajaran dengan menggunakan smartphone saat ini dijadikan kebutuhan sebagai upaya dalam memberi kemudahan pembelajaran, kegiatan belajar melalui media merupakan alat untuk mempermudah pengguna sebagai penyalur pesan maupun penerima informasi belajar (Kurniawan \& Syahputra, 2015). Sehingga peneliti berinisiatif menggunakan media berupa aplikasi berbasis android untuk mengembangkan produk berupa model latihan teknik dasar pukulan lob yang dikombinasikan dengan pukulan smash bulutangkis. Android merupakan platform berbasis kernel linux dari sistem operasi yang dikembangkan pertama kali oleh Android Inc yang didirikan oleh Andy Rubin (Zahid, 2018). Pada era milenial penggunaan smartphone android menjadi kebutuhan utama, media aplikasi berbasis android akan lebih efektif dan efisien sebagai sumber pengetahuan dalam kegiatan pembelajaran, sehingga memudahkan pelatih maupun atlet untuk mengakses model latihan melalui smartphone android.

Berdasarkan hasil analisis kebutuhan dengan wawancara pelatih dan 30 atlet di PB IMARA Kota Kediri pada tanggal 20 Juli 2020, untuk atlet dengan menyebar angket sehingga diperoleh hasil $100 \%$ atlet pernah diberikan program latihan pukulan lob dan smash bulutangkis, $100 \%$ latihan lebih banyak dengan virtual pada saat ini dikarenakan adanya pandemi covid-19, 20\% atlet tidak menerapkan program latihan yang diberikan oleh pelatih ketika dirumah saja di masa pandemi, $100 \%$ atlet tidak pernah diberi pembelajaran dengan media aplikasi berbasis android sebagai media dalam proses latihan, $100 \%$ atlet setuju jika pelatih menggunakan media aplikasi berbasis android sebagai media dalam proses latihan, $100 \%$ media aplikasi berbasis android mempermudah dalam mempelajari latihan teknik dasar pukulan lob yang dikombinasikan dengan pukulan smash bulutangkis, $83 \%$ atlet tidak memanfaatkan smartphone android untuk media pembelajaran bulutangkis, 100\% atlet setuju jika latihan teknik dasar pukulan lob dan smash bulutangkis ditambah variasi, 100\% dengan adanya media aplikasi berbasis android atlet termotivasi untuk mempelajari teknik dasar pukulan lob dan smash bulutangkis, $100 \%$ atlet setuju jika diadakan penelitian dan pengembangan mengenai produk berupa model latihan teknik dasar pukulan lob yang dikombinasikan dengan pukulan smash bulutangkis yang dikemas dalam media aplikasi berbasis android.

Adanya masalah-masalah yang ditemui oleh peneliti, dengan melakukan observasi awal untuk menganalisis kebutuhan, mengidentifikasi masalah, dan merumuskan tujuan, peneliti ingin melakukan penelitian dan pengembangan model latihan teknik dasar pukulan lob dan smash bulutangkis menggunakan media aplikasi berbasis android yang memiliki tujuan supaya variasi latihan tidak terkesan monoton, memotivasi atlet dalam mempelajari keterampilan 
pukulan lob dan smash sehingga materi latihan dapat diterima oleh atlet secara utuh dan latihan dapat berjalan lancer.

\section{Metode}

Penelitian ini menggunakan metode penelitian dan pengembangan Research and Development ( $R \& D$ ) dari Sugiyono (Sugiyono, 2012:298) terdapat sepuluh langkah prosedur pengembangan meliputi 1) Potensi dan masalah. 2) pengumpulan data, 3) Desain produk, 4) Validasi desain, 5) Revisi desain, 6) Uji coba produk, 7) Revisi produk, 8) Uji coba pemakaian, 9) Revisi produk, 10) produk massal. Dari sepuluh macam langkah di atas sebagian dimodifikasi oleh peneliti menjadi tujuh langkah dengan pertimbangan kebutuhan untuk menghasilkan produk. Prosedur pengembangan tersebut bukanlah prosedur baku yang harus diikuti secara keseluruhan (Ardhana, 2002) menyatakan bahwa peneliti memiliki kebutuhan yang berbeda dalam mengembangkan suatu produk, sehingga Tujuh langkah yang digunakan peneliti adalah 1) Potensi dan masalah, 2) Pengumpulan informasi, 3) Desain produk, 4) Uji coba produk, 5) Revisi desain, 6) Validasi desain. 7) Produk akhir.

Penelitian ini menggunakan data kuantitatif dan kualitatif, yang diperoleh dari hasil pengumpulan kuesioner dan dari hasil saran serta masukan berdasarkan ahli validasi dan atlet di PB IMARA Kota Kediri terhadap produk pengembaagan yang dihasilkan dari deskripsi keterlaksanaan uji coba produk.

\section{Hasil dan Pembahasan}

\subsection{Hasil}

Hasil analisis kebutuhan diperoleh dengan menyebar angket oleh 30 atlet PB IMARA sehingga diperoleh hasil $100 \%$ atlet pernah diberikan program latihan pukulan lob dan smash bulutangkis, $100 \%$ latihan lebih banyak dengan virtual pada saat ini dikarenakan adanya pandemi covid-19, 20\% atlet tidak menerapkan program latihan yang diberikan oleh pelatih ketika di rumah saja di masa pandemi, 100\% atlet tidak pernah diberi pembelajaran dengan media aplikasi berbasis android sebagai media dalam proses latihan, 100\% atlet setuju jika pelatih menggunakan media aplikasi berbasis android sebagai media dalam proses latihan, 100\% media aplikasi berbasis android mempermudah dalam mempelajari latihan teknik dasar pukulan lob yang dikombinasikan dengan pukulan smash bulutangkis, 83\% atlet tidak memanfaatkan smartphone android untuk untuk media pembelajaran bulutangkis, $100 \%$ atlet setuju jika latihan teknik dasar pukulan lob dan smash bulutangkis ditambah variasi, $100 \%$ dengan adanya media aplikasi berbasis android atlet termotivasi untuk mempelajari teknik dasar pukulan lob dan smash bulutangkis, $100 \%$ atlet setuju jika diadakan penelitian dan pengembangan mengenai produk berupa model latihan teknik dasar pukulan lob yang dikombinasikan dengan pukulan smash bulutangkis yang dikemas dalam media aplikasi berbasis android.

Desain produk yang telah dirancang sehingga diperoleh hasil dari validasi ahli bulutangkis sebesar $86 \%$, hasil validasi ahli media sebesar $90 \%$, selanjutnya hasil uji coba produk oleh kelompok kecil dan kelompok besar, kelompok kecil diperoleh hasil sebesar 88\% dilakukan dengan jumlah 8 atlet, kelompok besar diperoleh hasil sebesar $91 \%$ dilakukan dengan jumlah 22 atlet. 
Tabel 1. Data Hasil Uji Coba Kelompok Kecil

\begin{tabular}{cllc}
\hline No & \multicolumn{1}{c}{ Aspek } & Kelayakan & Kategori \\
\hline 1. & Ketepatan & $88 \%$ & Sangat Valid \\
2. & Kejelasan & $87 \%$ & Sangat Valid \\
3. & Kebermanfaatan & $90 \%$ & Sangat Valid \\
4. & Kemenarikan & $91 \%$ & Sangat Valid \\
5. & Kemudahan & $88 \%$ & Sangat Valid \\
\hline & Rata-rata & $88 \%$ & Sangat Valid \\
\hline
\end{tabular}

Sebesar 88\%, hasil tersebut berdasarkan pada aspek ketepatan sebesar 88\%, kejelasan sebesar 87\%, kebermanfaatan sebesar 90\%, kemenarikan sebesar 91\%, dan kemudahan sebesar $88 \%$ yang dikonversikan berdasarkan tabel klasifikasi kelayakan menunjukkan bahwa produk yang dikembangkan telah memenuhi kriteria sangat valid dan layak digunakan

Tabel 2. Data Hasil Uji Coba Kelompok Besar

\begin{tabular}{clll}
\hline No & \multicolumn{1}{c}{ Aspek } & Kelayakan & Kategori \\
\hline 1. & Ketepatan & $90 \%$ & Sangat Valid \\
2. & Kejelasan & $91 \%$ & Sangat Valid \\
3. & Kebermanfaatan & $92 \%$ & Sangat Valid \\
4. & Kemenarikan & $94 \%$ & Sangat Valid \\
5. & Kemudahan & $90 \%$ & Sangat Valid \\
\hline & Rata-rata & $91 \%$ & Sangat Valid \\
\hline
\end{tabular}

Diperoleh Hasil analisis data Uji coba produk yang terakhir pada tabel di atas dengan persentase sebesar 91\%, hasil tersebut berdasarkan pada aspek ketepatan sebesar $90 \%$, kejelasan sebesar 91\%, kebermanfaatan sebesar 92\%, kemenarikan sebesar 94\%, dan kemudahan sebesar 90\% yang dikonversikan berdasarkan tabel klasifikasi kelayakan menunjukkan bahwa produk pengembangan model latihan teknik dasar pukulan lob dan smash bulutangkis usia 8-12 tahun di PB IMARA Kota Kediri berbasis android telah memenuhi kriteria sangat valid dan layak digunakan.

\subsection{Pembahasan}

Bulutangkis merupakan salah satu cabang olahraga yang memerlukan hampir seluruh komponen fisik dan disertai dengan latihan teknik sebagai penunjang tingkat keakuratan pukulan yang dihasilkan. Keterampilan dasar permainan bulutangkis merupakan syarat yang harus dikuasai pemain diantaranya cara pegangan raket, sikap berdiri, kerja kaki, dan pukulan (Yuliawan, 2017). terdapat dua tipe permainan bulutangkis yaitu tipe permainan lama lebih menekankan faktor keindahan untuk meraih kemenangan, tipe modern mengutamakan faktor kemenangan dalam waktu singkat (Nandika et al., 2017). Pola permainan bulutangkis kurang lengkap jika tidak memahami peraturan dan teknik permainannya. Permainan dalam bulutangkis tidak tertuju hanya dari segi orientasi kematangan keterampilan pemain, tetapi tertuju pada segi permainan yang mengandalkan kelincahan, sehingga perlu adanya penunjang dalam meningkatkan kematangan pemain yaitu dengan kemampuan fisik serta kebugaran jasmani yang baik pada atlet (Haritsa \& Trisnowiyanto, 2016). Saat ini banyak berdirinya klubklub bulutangkis di Indonesia. Klub-klub bulutangkis tersebut memiliki produk yang berbeda untuk mengembangkan keterampilan bulutangkis berdasarkan tingkatan usia dalam mencapai 
prestasi, sehingga sering diadakan suatu kejuaraan sebagai penyalur bakat dan pencapaian prestasi. Klub olahraga harus memiliki latar belakang dan perencanaan pembinaan bulutangkis yang jelas untuk atletnya, tidak hanya asal berdiri tetapi memiliki program terencana untuk memajukan atlet (Santoso et al., 2017).

Atlet bulutangkis di PB IMARA masih kurang pada tingkat keterampilan akurasi pukulan lob dengan pukulan smash, hal tersebut diketahui ketika atlet melakukan kegiatan latihan. Kurang adanya variasi pukulan lob dengan pukulan smash. pukulan tersebut menjadi salah satu pukulan menyerang sebagai penguasaan teknik dasar pukulan atlet dalam menghasilkan point. Pukulan lob digunakan untuk menyerang maupun bertahan, sedangkan pukulan smash bertujuan untuk mematikan pertahanan lawan. kesalahan pada penempatan shuttlecock terjadi ketika lawan memberikan umpan tanggung, sehingga memberikan kesempatan dalam melakukan pukulan smash untuk mematikan pertahanan lawan (M. Phomsoupha \& Laffaye, 2014). Seorang pelatih harus mampu memberikan materi latihan yang bertujuan untuk mengembangkan faktor pendukung terciptanya hasil yang maksimal, karena pukulan lob dan smash bulutangkis paling banyak memerlukan tenaga. Karakteristik usia 8-12 tahun masuk kategori Learning to Train, mulai memperkenalkan berbagai macam keterampilan dan mengembangkan keterampilan bulutangkis yang mendasar (Badminton For Life Badminton Long-Term Athlete Development, 2009). Pemberian porsi latihan harus disesuaikan dengan karakteristik atletnya, agar tidak adanya beban yang berlebih pada setiap atlet, sehingga materi latihan dapat diterima sebagai penunjang dalam meningkatkan prestasi.

Pencapaian prestasi dalam olahraga perlu banyak hal yang harus diupayakan, diantaranya dengan metode latihan, pencapaian prestasi maksimal dapat diperoleh dengan proses latihan yang benar dan terprogram sebagai kebutuhan utama seorang atlet dari segi kondisi fisik, kemampuan mental, penguasaan teknik dan taktik melalui pembinaan sesuai program latihan yang telah diberikan oleh pelatih (Hidayat et al., 2019). oleh karena itu dengan adanya produk yang dikembangkan peneliti yang tujuannya untuk memudahkan pelatih dalam memberikan materi latihan sesuai dengan kebutuhan atletnya. Produk yang dikembangkan akan digunakan sebagai proses latihan untuk dijadikan acuan pembelajaran atlet berupa sepuluh model latihan teknik dasar pukulan lob dan smash bulutangkis di PB IMARA Kota Kediri dengan media aplikasi berbasis android. berkembangnya Ilmu pengetahuan dan teknologi saat ini dapat dikendalikan oleh aktivitas manusia, seperti penelitian yang dilakukan oleh (Astuti et al., 2018). dimana banyaknya pengguna perangkat mobile dikalangan pelajar sehingga peluang teknologi di dunia pendidikan semakin besar, hal tersebut menjadi prospek penggunaan smartphone menjadi lebih bermanfaat. Dengan adanya smartphone android sebagai media pembelajaran akan mengurangi dampak negatif seperti contoh bermain game. Untuk mendapatkan prestasi dalam bidang olahraga melalui pembinaan secara sistematis, dan atlet yang memiliki motivasi tinggi akan terdorong menjalankan latihan yang diberikan pelatih untuk mencapai tujuan yang ditetapkan (Clarasasti \& Jatmika, 2017)

\section{Simpulan}

Penelitian yang dikembangkan berdasarkan analisis data, sehingga disimpulkan bahwa pengembangan ini menghasilkan produk berupa model latihan teknik dasar pukulan lob dan smash bulutangkis usia 8-12 tahun di PB IMARA Kota Kediri menggunakan media aplikasi berbasis android model latihan tersebut dinilai berdasarkan uji validasi oleh ahli bulutangkis dan ahli media, dengan melalui tahapan revisi, hingga dilakukannya uji coba produk yang terakhir, sehingga mendapatkan persentase sebesar 91\%, berdasarkan tabel klasifikasi 
kelayakan, hasil tersebut menunjukkan bahwa penelitian ini telah memenuhi kriteria sangat valid dan layak digunakan. Dengan adanya media latihan berbasis android ini dapat membantu meningkatkan motivasi, menambah pengetahuan tentang pembelajaran bulutangkis, meningkatkan keterampilan pukulan lob dan smash bulutangkis, dan dapat mengalihkan efek negatif atlet dalam menggunakan smartphone yang lebih dimanfaatkan sebagai media pembelajaran bulutangkis.

\section{Daftar Rujukan}

Aditia, D. A. (2015). Penerapan Nilai-Nilai Positif Olahraga Dalam Interaksi Sosial Antar Siswa di SMA. ACTIVE. Journal of Physical Education, Sport, Health and Recreation, 4(12)., 4, 12.

Astuti, I. A. D., Dasmo, D., \& Sumarni, R. A. (2018). Pengembangan Media Pembelajaran Berbasis Android Dengan Menggunakan Aplikasi Appypie Di Smk Bina Mandiri Depok. Jurnal Pengabdian Kepada Masyarakat, 24(2), 695. https://doi.org/10.24114/jpkm.v24i2.10525

Badminton For Life Badminton Long-term Athlete Development. (2009). Ontario Ottawa: Badminton Canada.

Bafirman, H. (2013). Kontribusi Fisiologi Olahraga Mengatasi Resiko Menuju Prestasi Optimal. Media Ilmu Keolahragaan Indonesia, 3(1). https://doi.org/10.15294/miki.v3i1.2659

Clarasasti, E. I., \& Jatmika, D. (2017). Pengaruh Kecemasan Berolahraga terhadap Motivasi Berprestasi Atlet Bulutangkis Remaja di Klub J Jakarta. Humanitas (Jurnal Psikologi), 1(2), 121. https://doi.org/10.28932/humanitas.v1i2.421

Harista, N. F., \& Trisnowiyanto, B. (2016). Perbedaan Efek Latihan Medicine Ball Dan Clapping Push Up Terhadap Daya Ledak Otot Lengan Pemain Bulutangkis Remaja Usia 13-16 Tahun. Jurnal Kesehatan, 9(1), 51-60.

Hidayat, R., Kristiyanto, A., \& Riyadi, S. (2019). Manajemen Pembinaan Klub Bulutangkis Kabupaten Boyolali Tahun 2019. Proceedings of the National Seminar on Women's Gait in Sports towards a Healthy Lifestyle, April, 1-4.

Kurniawan, H., \& Syahputra, D. A. (2013). PERANCANGAN APLIKASI PEMBELAJARAN JARAK JAUH SEBAGAI MEDIA TAMBAHAN PENDUKUNG PROSES BELAJAR DAN MENGAJAR. SEMNASTEKNOMEDIA ONLINE, 3(1), 3-5.

Mangun, F. A., Budiningsih, M., \& Sugianto, A. (2017). Model Latihan Smash Pada Cabang Olahraga Bulutangkis Untuk Atlet Ganda. Gladi Jurnal Ilmu Keolahragaan, 8(2), 78-89. https://doi.org/10.21009/gjik.082.01

Nandika, R., Hadi, D. T., \& Ridho, Z. A. (2017). Pengembangan Model Latihan Strokes Bulutangkis Berbasis Footwork Untuk Anak Usia Pemula (U-15). Gladi Jurnal Ilmu Keolahragaan, 8(2), 102-110. https://doi.org/10.21009/gjik.082.03

Phomsoupha, M., \& Laffaye, G. (2014). Shuttlecock velocity during a smash stroke in badminton evolves linearly with skill level. Computer Methods in Biomechanics and Biomedical Engineering, 17(SUPP1), 140-141. https://doi.org/10.1080/10255842.2014.931550

Phomsoupha, Michael, \& Laffaye, G. (2015). The Science of Badminton: Game Characteristics, Anthropometry, Physiology, Visual Fitness and Biomechanics. Sports Medicine, 45(4), 473-495. https://doi.org/10.1007/s40279-014-0287-2

Santoso, H. P., Rahayu, T., \& Rahayu, S. (2017). Journal of Physical Education and Sports Pembinaan Bulutangkis di Kota Magelang ( Penelitian Evaluatif Klub-klub Bulutangkis di Kota Magelang ) Abstrak. Journal of Physical Education and Sports,6(2),133-140.

Sugiyono. (2012). Metode Penelitian kuantitatif kualitatif dan R\&D. Cetakan Ke-17.Bandung:Alfabeta.

Yuliatin, E., \& Noor, M. (2012). Bugar dengan Olahraga. Jakarta:PT Balai Pustaka (Persero).

Yuliawan, D. (2017). Bulu tangkis dasar. Yogyakarta:Deepublish.

Zahid, M. Z. (2018, February). Aplikasi berbasis android untuk pembelajaran: Potensi dan metode pengembangan. In PRISMA, Prosiding Seminar Nasional Matematika (Vol. 1, pp. 910-918). 